\title{
Ekstrak Propolis Lokal Mempunyai Efek Sitotoksik dan Antiproliferatif Terhadap Sel HeLa
}

\author{
Zauhani Kusnul Hadiyah*, Sri Widyarti**, Muhamad Aris Widodo*** \\ *Akademi Keperawatan Bahrul Ulum Jombang \\ **Laboratorium Biologi Molekuler Fakultas MIPA/Biologi Universitas Brawijaya \\ ***Laboratorium Farmakologi Fakultas Kedokteran Universitas Brawijaya
}

\begin{abstract}
Propolis is resin with complex chemical composition that collected by honeybees from various plants. It has been known that propolis has several biological properties, such as antimicrobial, anti-inflammatory, antioxidant and immunomodulatory activities. The aim of this study is to evaluate the propolis's cytotoxic and antiproliferative activity in vitro on hela cell line. These cells were incubated with different concentrations of propolis $(5,10,25,50$, and $100 \mu \mathrm{g} / \mathrm{ml})$ for different time periods $(6,24$, dan 48 hours), and the number of viable and died cells were analyzed by trypan blue dye exclution and were counted using hemocytometer. The result of this study showed that the IC50 of local propolis against HeLa cell line is $27,725 \mu \mathrm{g} / \mathrm{ml}$. It can be concluded that local propolis extract exhibited a cytotoxic and antiproliferatif effect in vitro against HeLa cell line, in a dose- and time dependent.
\end{abstract}

Key words: propolis, cytotoxic, antiproliferative, HeLa cell line

\section{PENDAHULUAN}

Propolis telah lama dikenal dan digunakan sebagai obat tradisional yang memiliki berbagai efek menguntungkan meliputi anti bakteri, anti fungi, anti inflamasi, anti virus, imunostimulator, dan anti kanker(1). Bahkan dalam kitab suci umat Islam (AlQur'an), produk lebah ini secara khusus disebut sebagai obat bagi manusia (An-Nahl: 68-69).

Penelitian efek antikanker propolis baik secara in vivo maupun in vitro telah dilakukan dalam bentuk ekstrak propolis maupun isolasi bahan aktifnya. Diantaranya propolis memperlihatkan efek sitotoksik terhadap sel HEp-2 in vitro yang dipengaruhi dosis dan waktu (2). Efek antiproliferasi pada sel tumor diduga merupakan efek sinergis dari unsur-unsur dalam propolis, diantaranya caffeic acid phenethyl ester (CAPE) yang merupakan salah satu unsur dalam propolis yang diteliti terkait aktivitas antitumor(3). Caffeic acid phenethyl ester memiliki efek yang dipengaruhi dosis terhadap sel glioma C6 dalam menekan jumlah sel hidup sebesar dan meningkatkan proporsi hypodiploid DNA sebagai indikasi apoptosis(4). Efek CAPE juga mempengaruhi siklus sel. Setelah inkubasi dengan CAPE selama 24 jam, jumlah persentase sel glioma C6 pada fase G0/G1 meningkat $85 \%$ melalui hambatan pada phosporilasi protein retinoblastoma (pRB) (5). Selain CAPE, flavonoid dan derivatnya yang juga merupakan komponen polyphenol. Asupan makanan kaya poliphenol khususnya flavonoid berkaitan dengan penurunan resiko terjadinya kanker. Beberapa komponen poliphenol meregulasi gen penting yang mengontrol proliferasi,

Jurnal Kedokteran Brawijaya, Vol. XXV, No. 1, April 2009; Korespondensi: Zauhani Kusnul H, Akper Bahrul Ulum Jombang Malang, Telp:081330897312 siklus sel, dan apoptosis pada sel kanker(6).

Komposisi propolis sangat bervariasi antar wilayah, apalagi antar negara dengan musim berbeda. Perbedaan ini disebabkan perbedaan jenis tanaman disekitar lebah penghasil propolis. Bahkan di negara dengan perbedaan musim yang ekstrim komposisi propolis di tempat yang sama bisa berbeda pada musim yang berbeda. Fakta diatas menimbulkan ketertarikan untuk mengkaji apakah propolis Indonesia, khususnya produk lebah dari lingkungan flora tropis Jawa Timur (Batu-Malang) memiliki aktifitas sitotoksik dan penurunan proliferasi sel kanker sehingga bisa menjadi alternatif sebagai kandidat pengobatan kanker.

\section{METODE}

Penelitian dilakukan dengan desain post test onlycontrol group design yang dilakukan di laboratorium secara in vitro dengan menggunakan rancangan acak lengkap. Banyaknya pengulangan pada kelompok perlakuan 3 (tiga) kali untuk lima perlakuan $(5,10,25,50$ dan $100 \mu \mathrm{g} / \mathrm{ml})$ dan tiga waktu pengamatan $(6,24$, dan 48 jam).

\section{Prosedur Ekstrak Propolis}

Sampel ekstrak propolis didapat dari peternakan lebah KUD Batu Malang. Ekstrak propolis diproses dengan cara: $100 \mathrm{gr}$ propolis ditumbuk dan direndam dalam etanol $96 \%$ selama 18 jam, Larutan ini disentrifuse dengan $7000 \mathrm{rpm}$ pada suhu $20^{\circ} \mathrm{C}$ selama 15 menit, supernatan diambil dan disaring. Untuk mengetahui berat kering ekstrak propolis dilakukan pengeringan dengan evaporator kemudian diukur berat keringnya per $\mathrm{ml}(\mathrm{mg} / \mathrm{ml})$. Untuk perlakuan, propolis dilarutkan pada Modified Eagle Media (MEM) hingga didapatkan beberapa konsentrasi berbeda $(5,10,25,50$ dan $100 \mu \mathrm{g} / \mathrm{ml})$. 


\section{Prosedur Kultur sel HeLa}

Stok sel HeLa ditumbuhkan dalam medium MEM (Modified Eagle Media) yang diberi penicillin $(100 \mathrm{U} / \mathrm{ml})$, streptomicyn $(100 \mathrm{U} / \mathrm{ml})$, dan $10 \% \mathrm{FBS}$. Diinkubasi pada inkubator dengan $\mathrm{CO}_{2} 5 \%$ dan suhu $37^{\circ} \mathrm{C}$ sampai konfluen. Untuk menghitung jumlah sel perlakuan dilakukan tripsinisasi dan dilakukan penghitungan standart jumlah sel per $\mathrm{ml}$ dengan hemocytometer sehingga akan diketahui jumlah sel per ml.

\section{Prosedur Perlakuan}

Sel HeLa dengan konsentrasi $1 \times 10^{6} \mathrm{sel} /$ sumuran didistribusikan ke dalam plate 24 sumuran dan diinkubasi selama 24 jam untuk beradaptasi dan menempel di sumuran sampai $70 \%$ konfluen. Keesokannya media dibuang, kemudian diganti media yang mengandung ekstrak propolis dalam berbagai konsentrasi $(5,10,25,50$, dan 100) $\mu \mathrm{g} / \mathrm{ml}$ dan diinkubasi selama 6, 24, dan 48 jam.

\section{Uji Sitotoksik (IC $\left.\mathrm{C}_{50}\right)$}

Uji sitotoksik dilakukan untuk mengetahui potensi sitotoksik ekstrak propolis terhadap sel HeLa dengan parameter $I_{50}$. Uji dilakukan dengan menginkubasi $1.5 \times 10^{6}$ sel HeLa dengan seri kadar propolis $5,10,25,50$, dan $100 \mu \mathrm{g} / \mathrm{ml}$ dan masingmasing diinkubasi selama 6, 24, dan 48 jam. Kematian sel yang terjadi pada masing-masing perlakuan diperiksa dengan pemeriksaan tripan blue, sel mati mengalami kerusakan membran dan menyerap warna biru, kemudian dihitung secara langsung dengan hemocytometer. Sel mati akan tampak berwarna biru dengan inti terwarnai(7).

\section{Uji doubling time}

Dengan prosedur yang sama seperti uji sitotoksik, jumlah total sel dihitung untuk menentukan waktu yang dibutuhkan sel untuk menjadi berjumlah dua kali lipat. Hasil digambarkan sebagai kurva jumlah sel vs waktu inkubasi(8).

\section{Analisis Data}

Untuk menguji apakah ada hubungan antara konsentrasi ekstrak propolis dengan laju kematian dan laju proliferasi sel HeLa, data yang didapat diuji secara statistik dengan uji korelasi spearman SPSS 12.

\section{HASIL PENELITIAN}

\section{Efek Sitotoksik Ekstrak Propolis terhadap Sel HeLa}

Kematian sel HeLa setelah inkubasi dengan seri ekstrak propolis pada pengamatan jam ke 6, 24, dan 48 jam disajikan dalam bentuk persentase sel mati terhadap total sel. Dari data tersebut tampak bahwa terdapat kecenderungan peningkatan persentase kematian sel seiring dengan peningkatan konsentrasi propolis dan lama inkubasi sel dengan ekstrak propolis. Pada pengamatan jam ke 6 setelah inkubasi persentase kematian tertinggi sebesar $25,5 \%$ terjadi pada sel dengan perlakuan $100 \mu \mathrm{g} / \mathrm{ml}$. Pada 24 jam setelah perlakuan, peningkatan persentase kematian sel tampak lebih nyata dimana pada konsentrasi $25 \mu \mathrm{g} / \mathrm{ml}$ kematian sel mencapai $42,2 \%$ kemudian meningkat menjadi 76,4 dan $66,8 \%$ pada konsentrasi 50 dan $100 \mu \mathrm{g} / \mathrm{ml}$. Kecenderungan peningkatan persentase kematian sel juga tampak pada pengamatan jam ke 48, dimana persentase kematian sel dengan dosis ekstrak propolis 25, 50, dan $100 \mu \mathrm{g} / \mathrm{ml}$ terus meningkat mencapai angka $97,8 \%$.

Kecenderungan peningkatan persentase kematian sel juga tampak pada pengamatan selanjutnya, pada 48 jam setelah perlakuan, dimana persentase kematian sel dengan konsentrasi 25, 50, dan 100 $\mu \mathrm{g} / \mathrm{ml}$ terus meningkat hingga mendekati angka $100 \%$. Sedangkan pada sel dengan perlakuan konsentrasi 5 dan $10 \mu \mathrm{g} / \mathrm{ml}$, kenaikan prosentase kematian juga terjadi terutama pada 48 jam setelah perlakuan. Grafik peningkatan kematian sel disajikan pada Gambar 1.

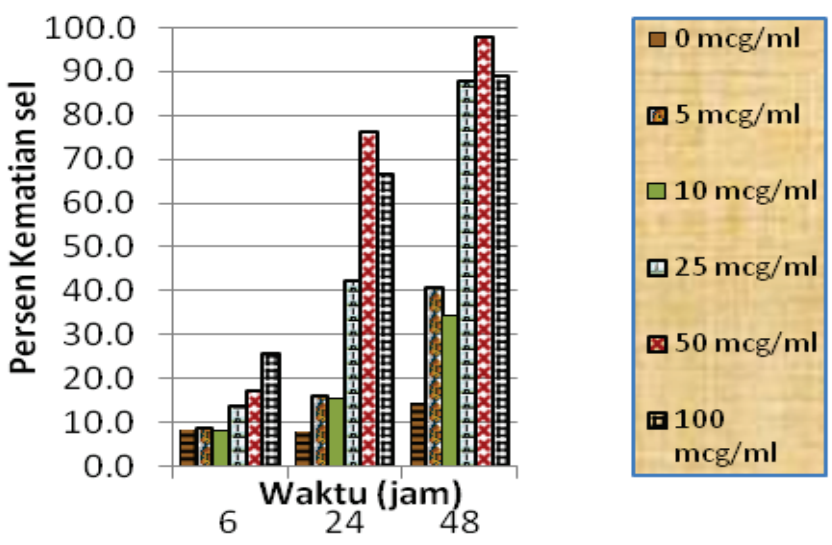

Gambar 1. Persentase Kematian Sel HeLa setelah Inkubasi dengan Ekstrak Propolis menurut Dosis dan Waktu Inkubasi.

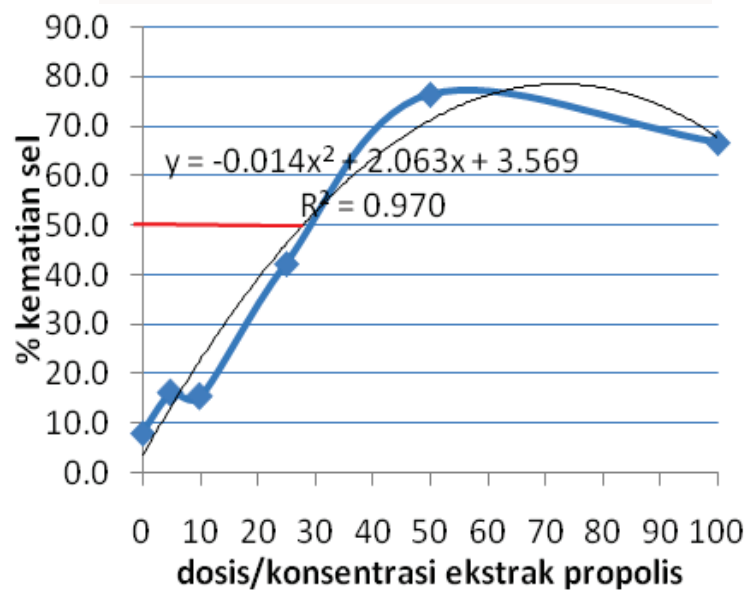

Gambar 2. IC $_{50}$ Ekstrak Propolis terhadap Sel HeLa.

Data diatas menunjukkan bahwa efek sitotoksik ekstrak propolis terhadap sel HeLa dipengaruhi oleh konsentrasi dan waktu inkubasi. Pada masa inkubasi yang sama peningkatan konsentrasi ekstrak propolis menyebabkan peningkatan persentase kematian sel. Demikian juga pada konsentrasi ekstrak propolis yang sama peningkatan waktu inkubasi sel menyebabkan peningkatan 
persentase kematian sel. Kematian sel sebesar $50 \%$ tampak dapat dicapai sebelum inkubasi 24 jam dengan perlakuan 50 dan $100 \mu \mathrm{g} / \mathrm{ml}$ propolis, propolis $25 \mu \mathrm{g} / \mathrm{ml}$ menyebabkan kematian setelah jam ke 24 .

Dalam grafik persentase kematian sel terhadap konsentrasi (Gambar 2) dapat dilihat bahwa $I_{50}$ dapat dicapai pada perlakuan dengan konsentrasi ekstrak $25 \mu \mathrm{g} / \mathrm{ml}$ atau lebih, perlakuan dengan 5 dan $10 \mu \mathrm{g} / \mathrm{ml}$ tidak mencapai kematian sel $50 \%$.
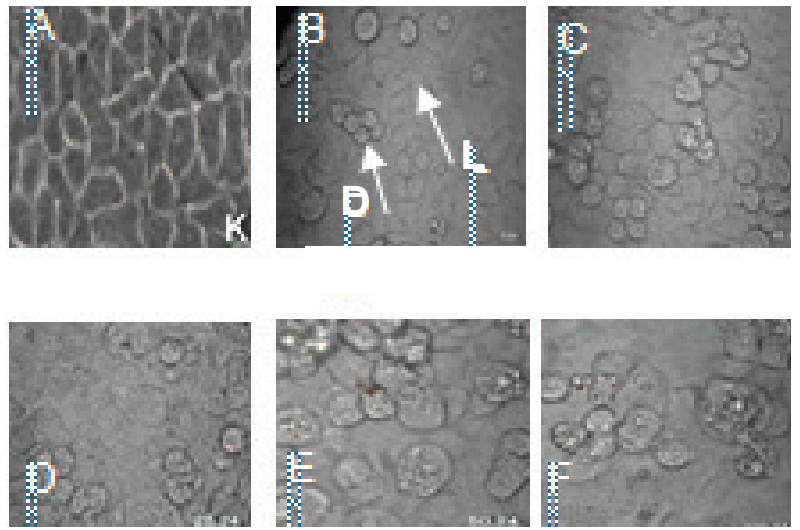

Gambar 3. Tampilan Mikroskopis Sel Hela setelah Inkubasi Selama 24 Jam dengan Propolis dibanding dengan Kontrol (L; hidup, D; mati).

\section{Keterangan:}

A. Sel Kontrol (tanpa propolis)

B. Sel dengan $5 \mu \mathrm{g} / \mathrm{ml}$ propolis

C. Sel dengan $10 \mu \mathrm{g} / \mathrm{ml}$ propolis

D. Sel dengan $25 \mu \mathrm{g} / \mathrm{ml}$ propolis

E. Sel dengan $50 \mu \mathrm{g} / \mathrm{ml}$ propolis

F. Sel dengan $100 \mu \mathrm{g} / \mathrm{ml}$ propolis

Dari tampilan mikroskopis sel dapat dilihat jelas perubahan yang terjadi pada sel antar perlakuan dibandingkan dengan kontrol. Sel kontrol tampak berbentuk pipih, memiliki sudut tajam dan menempel di dasar sumuran. Sel dengan perlakuan $5 \mu \mathrm{g} / \mathrm{ml}$ menampakkan adanya sel yang mulai mengalami proses kerusakan/ kematian.Kerusakan sel tampak dari bentuknya yang bulat dan terlepas dari tempat menempelnya di dasar sumuran. Pada kelompok sel dengan perlakuan 10, 25, 50, dan 100 $\mu \mathrm{g} / \mathrm{ml}$ tampak sel yang mengalami proses kematian menjadi makin banyak. Adanya hubungan antara konsentrasi dan kematian sel HeLa juga diperkuat dengan hasil uji korelasi sperman's SPSS 12 yang menunjukkan terdapat korelasi positif yang kuat antara konsentrasi perlakuan dengan kematian sel baik pada pengamatan jam ke 6,24 , maupun 48 jam setelah perlakuan dengan koefisien korelasi masing-masing $0,943,0,886$ dan 0,886 dan dengan taraf signifikansi $0,005,0,019$, dan 0,019. Artinya peningkatan konsentrasi ekstrak propolis secara bermakna menyebabkan peningkatan kematian sel HeLa.

\section{Efek Antiproliferatif Ekstak Propolis Terhadap Sel HeLa}

Efek pemberian ekstrak propolis terhadap proliferasi sel HeLa diukur dengan menghitung jumlah sel pada tiap kelompok pada akhir masing- masing lama inkubasi. Data menunjukkan bahwa ekstrak propolis menyebabkan hambatan terhadap proliferasi sel HeLa. Pada pengamatan jam ke 6 setelah perlakuan, sel tanpa propolis mengalami penambahan jumlah menjadi $139 \%$ dari jumlah sel semula, sedang sel dengan perlakuan mengalami penurunan jumlah sel namun dalam prosentase yang masih relatif kecil (4-18\%).

Pada pengamatan selanjutnya (24 jam setelah pemberian ekstrak propolis) terjadi perbedaan yang cukup ekstrim dimana sel kontrol meningkat pesat menjadi $306 \%$ dari sel semula, dan sel dengan ekstrak propolis $5 \mathrm{\mu g} / \mathrm{ml}$ mencapai $245 \% \mathrm{jml}$ semula. Sel dengan ekstrak propolis 10 dan 25 $\mu \mathrm{g} / \mathrm{ml}$ masih mengalami peningkatan jumlah namun keduanya tidak mencapai dua kali lipat jumlah sel semula (164\% dan $136 \%$ ), sedangkan sel dengan perlakuan 50 dan $100 \mu \mathrm{g} / \mathrm{ml}$ justru mengalami penurunan jumlah sel menjadi lebih rendah dari jumlah semula(64\% dan $46 \%)$.

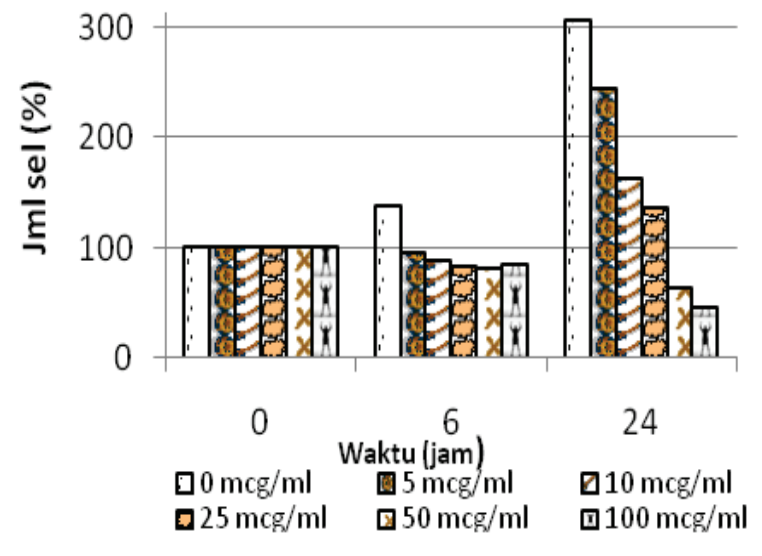

Gambar 4. Pertumbuhan Sel HeLa.

Efek penghambatan yang disebabkan ekstrak propolis terhadap laju proliferasi sel Hela juga dapat diidentifikasi dengan menghitung waktu yang dibutuhkan kelompok sel untuk berkembang menjadi dua kai lipat jumlah semula (doubling time). Pada penelitian ini doubling time hanya ditemukan pada kelompok sel tanpa ekstrak propolis dan kelompok dengan ekstrak propolis $5 \mu \mathrm{g} / \mathrm{ml}$ (Gambar 4).

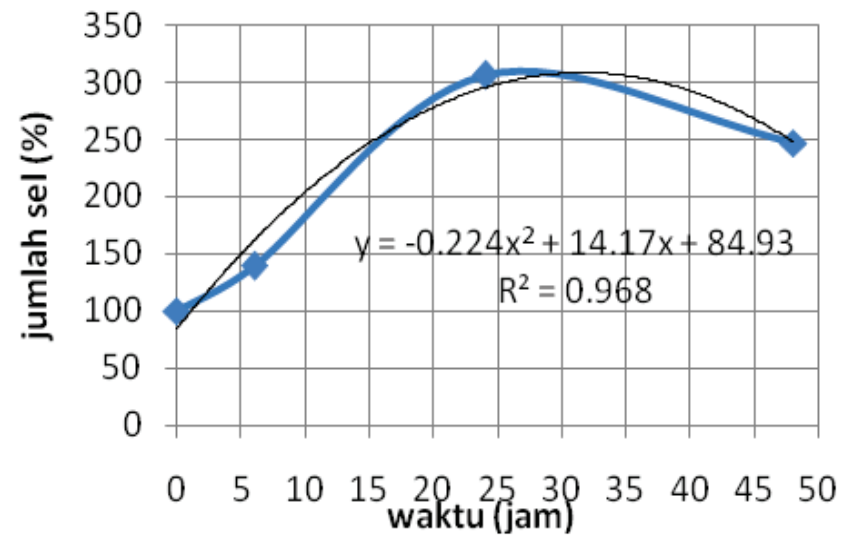

Gambar 5. Laju Pertumbuhan Sel Tanpa Ekstrak Propolis. 
Gambar 5 menunjukkan nilai $R^{2}=0,968$ (korelasi kuat) yang signifikan. Dari persamaan dapat ditentukan waktu yang dibutuhkan sel tanpa ekstrak propolis untuk mencapai dua kali lipat adalah 9,57 $\pm 0,032$ jam.

\section{Laju pertumbuhan sel dengan $5 \mathrm{mcg} / \mathrm{ml}$ propolis}

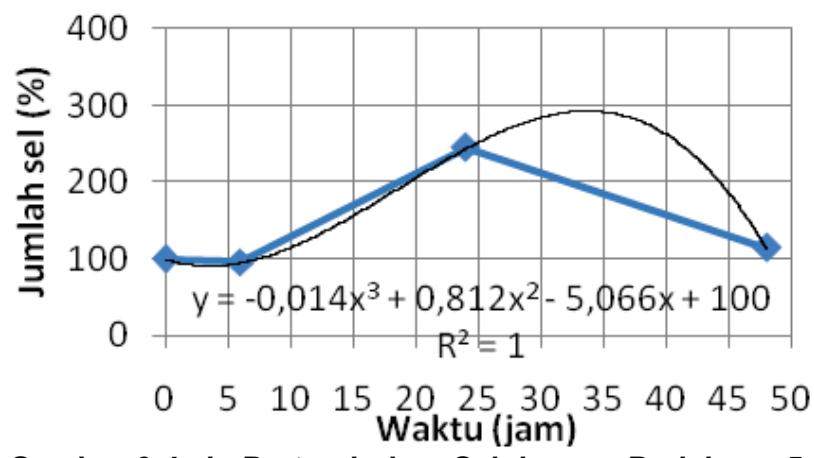

Gambar 6. Laju Pertumbuhan Sel dengan Perlakuan 5 $\mu \mathrm{g} / \mathrm{ml}$ Propolis.

Laju pertumbuhan sel pada dosis $5 \mu \mathrm{g} / \mathrm{ml}$ menunjukkan korelasi sempurna, dengan nilai $\mathrm{R}^{2}=1$ (Gambar 6). Dari persamaan dapat ditentukan waktu yang dibutuhkan sel dengan perlakuan $5 \mu \mathrm{g} / \mathrm{ml}$ propolis untuk mencapai dua kali lipat adalah 18,9 jam. Waktu yang diperlukan tersebut dua kali lebih lama dibanding sel kontrol.

Hasil uji korelasi spearman's antara dosis perlakuan dengan proliferasi sel menampakkan hasil bahwa terdapat korelasi negatif yang kuat dan signifikan. pada pengamatan jam ke 6, 24, maupun 48 jam setelah perlakuan dengan koefisien korelasi masing-masing $-0,812,-1$, dan 0,943 dan dengan taraf signifikansi $0,05,0,0$, dan 0,005 . Artinya peningkatan konsentrasi ekstrak propolis secara bermakna menyebabkan penurunan proliferasi sel HeLa.

\section{DISKUSI}

Dalam penelitian ini digunakan propolis produksi lokal daerah Batu dengan tujuan untuk mengeksplorasi dan memperkenalkan potensi yang dimiliki oleh produk lokal yang hingga kini belum banyak dikenal dan diteliti secara ilmiah. Kandungan bahan aktif dalam propolis lokal ini belum diidentifikasi, dan bisa memiliki komposisi yang berbeda dari produk propolis lain. Meskipun demikian penelitian menunjukkan efek yang serupa bisa ditimbulkan oleh propolis dari wilayah geografis yang berbeda dengan kandungan bahan aktif yang berbeda(10).

Sel HeLa digunakan dalam penelitian ini sebagai model yang mewakili karakteristik sel dengan tingkat proliferasi tinggi yang merupakan salah satu karakteristik sel kanker. Hasil penelitian ini diharapkan bisa membuka kemungkinan untuk diaplikasikan ke berbagai sel kanker lain.

Untuk mengidentifikasi sel yang mati digunakan pemeriksaan menggunakan tripan blue.
Pemeriksaan ini didasarkan pada permeabilitas membran, dengan asumsi bahwa sel yang memiliki membran yang permeabel telah mengalami kerusakan yang ireversibel yang artinya sel tersebut mati. Sel yang mati akan menyerap warna biru sehingga dengan pemeriksaan mikroskopis akan tampak biru dengan inti terwarnai lebih gelap.

Pada penelitian ini propolis menampakkan efek sitotoksik terhadap sel HeLa in vitro yang dipengaruhi oleh dosis dan waktu. Konsentrasi propolis yang lebih tinggi memerlukan waktu yang lebih singkat untuk meyebabkan kematian sel. Sebaliknya konsentrasi lebih rendah membutuhkan waktu lebih panjang untuk menimbulkan efek yang sama. Hasil ini senada dengan penelitian sebelumnya yang dilakukan oleh Bu' falo dkk tahun 2007, tentang efek sitotoksik Brazilian green propolis terhadap sel HEp-2 in vitro(2).

Titik $I_{50}$ ekstrak propolis terhadap sel HeLa dalam penelitian ini berada pada konsentrasi 27, $725 \pm$ $0,03 \mu \mathrm{g} / \mathrm{ml}$, menunjukkan aktifitas sitotoksik yang cukup tinggi. Sehingga bisa dikatakan bahwa propolis lokal cukup menjanjikan untuk dikembangkan menjadi bahan yang berpotensi tinggi dalam penanganan penyakit kanker. Penelitian untuk menentukan konsentrasi $I_{50}$ ekstrak propolis sebelumnya juga pernah dilakukan oleh Chen pada tahun 2004 menggunakan Taiwanese propolis terhadap sel human melanoma. Pada penelitian ini didapatkan konsentrasi $I_{50}$ berkisar $20 \mu \mathrm{g} / \mathrm{ml}$. perbedaan ini mungkin disebabkan jenis dan karakteristik sel yang digunakan berbeda. Pada prinsipnya keduanya memiliki potensi efek sitotoksik yang sama baiknya.

Selain memicu kematian sel, aktifitas propolis juga tampak dari hambatanya terhadap perkembangan jumlah sel. Hal ini tampak dari memanjangnya waktu yang dibutuhkan sel dengan perlakuan 5 $\mu \mathrm{g} / \mathrm{ml}$ propolis untuk menjadi dua kali lipat jika dibandingkan dengan kontrol. Sel dengan perlakuan ekstrak konsentrasi lebih tinggi $(10,25$, 50, dan $100 \mu \mathrm{g} / \mathrm{ml}$ ) tidak mengalami doubling time. Data ini jelas sekali memggambarkan aktifitas antiproliferatif ekstrak propolis terhadap sel HeLa. Aktifitas sitotoksik dan antiproliferatif ekstrak propolis sangat mungkin merupakan hasil kerja sinergis dari bahan-bahan yang terkandung di dalamnya. Beberapa bahan aktif propolis telah diisolasi dan diteliti(3). Caffeic acid phenethyl ester merupakan salah satu kandungan bahan aktif dalam propolis yang banyak diteliti terkait aktifitas anti tumor. CAPE adalah kandungan phenol aktif yang ditemukan pada propolis, memiliki berat molekul 284,3 kDa. Selain itu CAPE memiliki efek yang dipengaruhi oleh dosis terhadap sel glioma C6, yaitu menekan jumlah sel hidup $42 \%$ dibandingkan dengan kontrol dan meningkatkan proporsi hypodiploid DNA sebagai indikasi apoptosis(4). CAPE juga mempengaruhi siklus sel. Setelah inkubasi dengan CAPE selama 24 jam, jumlah persentase sel glioma C6 pada fase G0/G1 meningkat $85 \%$ melalui hambatan pada phosporilasi protein retinoblastoma ( $p R B)$. 
Phosporilasi pRB oleh cyclin dependent kinase(CDK) dipercaya sebagai kejadian penting dalam regulasi memasuki fase $S$, dan sebagai titik restriksi.

Penghambatan pertumbuhan sel oleh CAPE terkait dengan efek pada proses oksidatif yang diinduksi oleh stimulus mitogen. Pengaturan proliferasi sel pada berbagai jenis tipe sel mamalia dimediatori oleh ikatan sitokin, growth factor, dan hormon yang spesifik terhadap reseptor permukaan sel yang selanjutnya menggerakan oksigen radikal dan $\mathrm{H}_{2} \mathrm{O}_{2}$. CAPE diketahui mampu menghambat proses oksidatif yang lebih luas atau sebanding dengan agen khemopreventif seperti tamoxifen(11). Flavonoid yang juga merupakan komponen penting dalam propolis menampakkan aktifitas menghambat proliferasi berbagai sel kanker dan pertumbuhan tumor pada berbagai hewan model(12). Menurut Agarwal, flavonoid menunjukkan aktifitas menghambat cyclin B, meningkatkan ekspresi p21 WAF (suatu inhibitor pertumbuhan), dan mengiduksi apoptosis. Juga memicu pelepasan sitokrom c ke sitosol, menginduksi procaspase 9 , dan mengaktifkan caspase 3(6).

Beberapa komponen poliphenol meregulasi gen penting yang mengontrol proliferasi, siklus sel, dan apoptosis pada sel kanker, flavanon menampakkan aktifitas mengiduksi apoptosis dengan mengaktifkan caspase 9 dan 3(6). Luteolin, subclass flavone dari flavonoid memiliki potensi antikanker dalam penelitian in vitro, luteolin menghambat proliferasi sel HLF tergantung pada konsentrasi dan lama inkubasi, penurunan jumlah sel sebesar $43,6 \%$ terjadi dengan pemberian luteolin $10 \mu \mathrm{mol} / \mathrm{L}$ selama 3 hari. $50 \mu \mathrm{mol} / \mathrm{L}$ luteolin menunjukkan induksi apoptosis yang nyata dalam 12 jam(13).

Pada penelitian yang lain, flavonoid aktif, quercetin juga merupakan produk bahan alam yang memiliki aktifitas antitumor dengan menghambat Cdk. Quercetin menampakkan aktifitas antitumor melalui penghambatan siklus sel pada interfase G0/G1, selaras dengan penghambatan $\mathrm{Cdk}$. Analog dengan quercetin, Myricetin juga menampakkan $\mathrm{IC}_{50}$ mendekati $10 \mu \mathrm{M}$ terhadap Cdk2. Flavopiridol menampakkan 100 kali lebih selektif terhadap Cdks dibanding aktifitasnya pada tyrosin kinase, dan merupakan komponen pertama yang diidentifikasi oleh $\mathrm{NCl}$ sebagai agen antitumor potensial(14). Flavon, epigenin, dan genistein juga merupakan agen yang potensial untuk kemoprevensi dan terapi kanker dimana ketiganya mampu meningkatkan sitotoksisitas TRAIL (Tumor Necrosis FactorRelated Apoptosis-Inducing Ligand) pada sel HeLa(15).

\section{KESIMPULAN}

Ekstrak propolis lokal memiliki aktifitas meningkatkan kematian dan menghambat proliferasi sel HeLa. Efek tersebut dipengaruhi oleh dosis dan waktu pemberian propolis.

\section{DAFTAR KEPUSTAKAAN}

1. Burdock GA. Review of the biological properties and toxicity of bee propolis (propolis). Food Chem Toxicol. 1998;36:34763.

2. Bu' falo C, Joa o M. G. Candeias and Jose' Maurı'cio Sforcin. In vitro cytotoxic effect of brazilian green propolis on human laryngeal epidermoid carcinoma (HEp-2) cells. Department of Microbiology and Immunology, Biosciences Institute, UNESP, 18618-000 Botucatu, S.P., Brazil;2007

3. Jin UH, Chung TW, Kang SK, et al. Caffeic acid phenyl ester in propolis is a strong inhibitor of matrix metalloproteinase-9 and invasion inhibitor: isolation and identification. Clin Chim Acta. 2005;362:5764.

4. Lee YJ, Kuo HC, Chu CY, Wang CJ, Lin WC, Tseng TH. Involvement of tumor suppressor protein p53 and p38 MAPK in caffeic acid phenethyl ester-induced apoptosis of C6 glioma cells.Biochem Pharmacol. 2003;66:22819.

5. Aso K, Kanno S, Tadano T, Satoh S, Ishikawa M. Inhibitory effect of propolis of the growth of human leukemia U937. Biol Pharm Bull. 2004;27:72730.

6. Agarwal, Bharat B, Shishir S. Moleculartargets of dietary agent for prevention and therapy of cancer. Biochemical Pharmacology. 2006; 71:1397-1421

7. Bassani-Silva S, Sforcin JM, Amaral AS, Gaspar LFJ, Rocha NS. Propolis effect in vitro on venereal transmissible canine tumor. Rev Port Cie^nc Vet, in press.

8. Doyle A, and Griffiths JB. Cell and tissue culture for medical research. England: John Willey \& Sons LTD; 2000

9. Meiyanto E, Ratna A, Handayani S dan Rahmi F. Ekstrak etanolik biji buah pinang (areca catechu I.) mampu menghambat proliferasi dan memacu apoptosis sel MCF-7. Majalah Farmasi Indonesia. 2008;19:1

10.Bankova VS, Castro SL, Marcucci MC. Propolis: recent advances in chemistry and plant origin. Apidologie. 2000;31:315

11.Bhimani HR, Troll, Grunberger D and Frenkel. K. Inhibition of oxidativc stress in HeLa cells by chemopreventive agents. Cancer Res. 1993;53: 4528-4533,

12.Kanadaswami C, Lee LT, Lee PP et al. The antitumor activities of flavonoids. In Vivo. 2005;19:895-909

13. Selvendiran K, Hironori K, Takato U, et al. Luteolin promotes degradation in signal transducer and activator of transcription 3 in human hepatoma cells: an implication for the antitumor potential of flavonoids. Cancer Res. 2006;66:9

14. Cragg GM, Newman DJ. EthnopharmacologyPlants as a source of anti-cancer agents. Natural products branch, developmental therapeutics program, division of cancer treatment and diagnosis. National Cancer 
Institute, Maryland. USA; 2005

15. Szliszka E, Czuba ZP, Jernas K and K Wojciech. Dietary flavonoids sensitize hela cells to tumor necrosis factor-related apoptosis-inducing ligand (TRAIL). Int. J. Mol. Sci. 2008;9:56-64 